\title{
Peningkatan Kemampuan UMKM dalam Melakukan Analisis Kelayakan Usaha Agar Dapat Bertahan di Masa Pandemi COVID-19
}

\author{
Nyimas Dewi Murnila Saputri ${ }^{1 *}$, Yuliani Yuliani ${ }^{1}$ dan Yulia Hamdaini Putri ${ }^{1}$ \\ ${ }^{1}$ Fakultas Ekonomi, Universitas Sriwijaya, Sumatera Selatan, Indonesia \\ *Email korespondensi: murnilasaputri@fe.unsri.ac.id
}

Info Artikel: Diterima: 06 Juli 2021; Disetujui: 18 Oktober 2021; Dipublikasi: 13 November 2021

\begin{abstract}
Dampak COVID-19 bukan hanya berpengaruh terhadap perubahan tatanan kehidupan sosial tetapi juga menurunkan kinerja perekonomian dunia. Kota Palembang adalah salah satu kota besar di Indonesia dimana mempunyai resiko terdampak penurunan ekonomi pada kegiatan UMKM. Kondisi pandemi diperkirakan belum pasti kapan akan berakhir. Hanya UMKM yang inovatif dan adaptif yang akan mampu untuk bertahan dimana salah satunya melalui diversifikasi. Diversifikasi usaha dapat dilakukan sebagai adaptasi usaha di masa pandemi. Studi kelayakan juga dapat digunakan dalam menilai dan menganalisis kelayakan dari diversifikasi usaha yang akan dilakukan. Untuk itulah kegiatan pengabdian kepada masyarakat melalui pelatihan diharapkan mampu meningkatkan kemampuan UMKM di Kota Palembang dalam melakukan analisis kelayakan usaha yang pada akhirnya mampu membuat UMKM bertahan di masa pandemi COVID-19.
\end{abstract}

Kata Kunci: COVID-19; UMKM; Analisis Kelayakan Usaha

Kutipan:

Saputri, N.D.M., Yuliani, Y., Putri, Y.H. (2021). Peningkatan Kemampuan UMKM dalam Melakukan Analisis Kelayakan Usaha Agar Dapat Bertahan di Masa Pandemi COVID-19. Sricommerce: Journal of Sriwijaya Community Services, 2(2): 177-181. DOI: https://doi.org/10.29259/jscs.v2i2.69

\section{PENDAHULUAN}

World Health Organization (WHO) mengumumkan wabah virus corona (COVID-19) secara resmi sebagai pandemi, dimana virus ini menginfeksi sistem pernafasan. Virus corona dapat ditularkan dari manusia ke manusia dimana diketahui menyebar di China secara luas dan lebih dari 190 negara dan teritori lainnya (Susilo, et all, 2020). Penyebaran virus ini sangat cepat ke berbagai negara diseluruh dunia, termasuk Indonesia. Kasus pertama COVID-19 di Indonesia di laporkan pada tanggal 2 Maret 2020 sebanyak dua kasus (Susilo, et all, 2020).

Dampak COVID-19 ini bukan hanya berpengaruh terhadap perubahan tatanan kehidupan sosial tetapi juga menurunkan kinerja perekonomian dunia, termasuk Indonesia. Seperti yang dinyatakan oleh Hanoatubun (2020) bahwa penyebaran virus Corona telah membawa dampak pada Perekonomian Indonesia. Menurut Badan Pusat Statistik turunnya kinerja ekonomi Indonesia terjadi sejak triwulan I tahun 2020, yang tercermin dari laju pertumbungan ekonomi yang hanya mencapai 2,97\% dan kembali menurun signifikan pada triwulan II tahun 2020 yang tumbuh minus $5,32 \%$.

Pemerintah Indonesia sendiri telah menetapkan berbagai kebijakan pencegahan penyebaran virus corona, salah satunya dengan menerapkan Pembatasan Sosial Berskala Besar (PSBB) di berbagai kota. PSBB sebagaimana yang diatur dalam Peraturan Pemerintah Republik Indonesia 
Nomor 21 Tahun 2020 tentang Pembatasan Sosial Berskala Besar meliputi:

1. Peliburan sekolah dan tempat kerja;

2. Pembatasan kegiatan keagamaan; dan/atau;

3. Pembatasan kegiatan di tempat atau fasilitas umum.

Pemberlakuan PSBB di beberapa wilayah di Indonesia memengaruhi operasional perusahaan dikarenakan adanya pembatasan dalam kegiatan dan pemberlakuan physical distancing. Berdasarkan survei dampak COVID-19 terhadap pelaku usaha yang dilakukan oleh Badan Pusat Statistik RI ada $8,76 \%$ usaha yang berhenti beroperasi. Ditengah kondisi pandemi seperti ini, pengusaha berupaya mempertahankan operasional usahanya.

Banyak perusahaan yang merumahkan tenaga kerjanya tanpa dibayar bahkan ada yang berdampak pada pemberhentian pekerja dikarenakan adanya pengurangan jam operasional kegiatan usaha yang dilakukan. Pengurangan jam operasional berdampak pada kinerja perusahaan tersebut dan juga kemungkinan sangat tinggi dalam penurunan margin perusahaan.

Aktivitas bisnis pelaku Usaha Mikro, Kecil, Menengah (UMKM) juga ikut terdampak efek dari pandemi ini. Amilia (2015) meyebutkan bahwa usaha Mikro Kecil dan Menengah memegang peranan yang penting bagi pertumbuhan ekonomi Indonesia. Hal ini sejalan dengan pernyataan Direktur Jenderal Pengelolaan Pembiayaan Risiko Kementerian Keuangan, Lucky Alfirman yang dikuti dalam berita Liputan6.com dimana menyebut peran UMKM sangat penting terhadap perekonomian Indonesia. Ketangguhan UMKM menjadi modal utama, membawa perekonomian nasional selamat dari krisis. Bank Indonesia (2015) menyatakan sebanyak 96\% UMKM tetap bertahan dari goncangan krisis yang terjadi di tahun 1998. Oleh sebab itu, perlu memberikan perhatian khusus mengenai kondisi pandemi terhadap pelaku UMKM.

Kota Palembang merupakan salah satu kota besar di Indonesia yang mempunyai resiko terdampak penurunan ekonomi pada kegiatan UMKM. Kondisi pandemi diperkirakan belum pasti kapan akan berakhir. Hanya UMKM yang adaptif dan inovatif yang akan mampu untuk bertahan. Kondisi pandemi, untuk sebagian pelaku usaha adalah peluang dengan merencanakan pengembangan usaha pasca COVID-19, untuk itulah studi kelayakan diperlukan.

\section{STUDI PUSTAKA}

\subsection{Usaha Mikro, Kecil dan Menengah (UMKM)}

Profil UMKM di Indonesia terdiri atas tiga kluster besar, yaitu kluster produsen, usaha dagang, dan jasa. Produsen umumnya memproduksi aneka makanan dan minuman seperti tahu, tempe, kue basah, bakso, mie, sirop, dll. Termasuk aneka sandang seperti pakaian/batik, tas, sepatu, kerajinan/souvenir, mebel, percetakan dan industri kreatif. Usaha dagang mencakup pedagang kaki lima, restoran, kafe, catering, aneka warung, kuliner, toko pakaian/fashion, toko sembako, dll. Sedangkan usaha jasa (service business) seperti transportasi online, travel wisata dan umroh, kontraktor, pengadaan barang/ jasa, bengkel, logistik, salon, klinik, barbershop, event organizer, desain dan percetakan, dll. Peranan strategis sektor Usaha Mikro, Kecil dan Menengah (UMKM) yakni kemampuan sektor ini menjadi pilar utama ekonomi Indonesia (Supriyanto, 2006)

\subsection{Studi Kelayakan Bisnis}

Skala bisnis yang menguntungkan yang dihasilkan dari kelayakan bisnis akan berdampak pada pengambilan kebijakan atau strategi bisnis yang diperlukan sehingga akan berdampak pada keberlangsungan usaha UMKM (Jayanto, Mukhibad, \& Kuat Waluyo, 2018). Studi kelayakan bisnis adalah proses yang terkontrol untuk mengidentifikasi masalah, peluang, menentukan tujuan, menggambarkan situasi, menentukan hasil yang sukses dan menilai berbagai biaya dan manfaat yang terkait dengan beberapa alternatif untuk memecahkan masalah. Studi kelayakan bisnis digunakan untuk mendukung proses pengambilan keputusan berdasarkan kelangsungan usaha atau proyek yang sebenarnya (Mavilinda et.al., 2021).

Studi kelayakan bisnis merupakan kegiatan untuk menilai sejauh mana manfaat yang dapat diperoleh dalam melaksanakan suatu kegiatan usaha atau proyek (Gumelar, 2011). Studi 
kelayakan proyek atau bisnis merupakan suatu kegiatan mengevaluasi, menganalisis, dan menilai layak atau tidak suatu proyek bisnis dijalankan (Afiyah, Saifi, \& Dwiatmanto, 2015). Dengan dilakukannya, studi kelayakan proyek berguna bagi pelaku usaha untuk menghindari keterlanjuran penanaman modal yang terlalu besar untuk suatu kegaiatn usaha yang ternyata tidak menguntungkan. Kelayakan bisnis dibuktikan dengan hasil usaha memberikan hasil yang lebih besar dari biaya yang dikeluarkan. Analisis kelayakan usaha yang dilakukan meliputi kelayakan dalam bidang hukum, keuangan, teknis, dan produksi, pemasaran dan manajemen.

\section{METODE}

Bentuk kegiatan pembinaan dan pengembangan dalam kegiatan pengabdian masyarakat ini adalah melakukan pelatihan terhadap UMKM dengan memberikan bantuan teknis berupa presentasi dan pelatihan sesuai kebutuhan, arahan dan konsultasi.

Kegiatan pelatihan dilakukan secara langsung tatap muka (offline), tetapi mengingat kondisi pandemi COVID-19, kegiatan dilakukan dengan menerapkan protokol kesehatan sesuai dengan anjuran pemerintah. Kegiatan pengabdian dilakukan dengan menjaga jarak. Agar kegiatan pelatihan tetap efektif, peserta dibatasi sejumlah kurang lebih 30 orang pelaku UMKM. Peserta kegiatan yang kurang memahami materi pelatihan, dapat bertanya langsung dengan kontak yang disediakan setelah sesi pelatihan berakhir.

Sistematika pelaksanaan kegiatan pengabdian ini adalah sebagai berikut:

1. Langkah 1 (Metode Presentasi dan Penyuluhan)

Pada langkah pertama, peserta pelatihan akan diberikan penjelasan dan pemahaman mengenai analisis kelayakan usaha, yang dapat diterapkan oleh UMKM dimana bertujuan untuk menilai kegiatan/strategi usaha yang tepat untuk dipilih.

2. Langkah 2 (praktek analisis kelayakan usaha)

Peserta diberikan pelatihan dalam penliaian kelayakan usaha UMKM berdasarkan aspekaspek yang telah dipaparkan.

3. Langkah 3 (Diskusi)

Peserta diberikan kesempatan untuk melakukan tanya jawab atau sharing permasalahan yang berkaitan dengan analisis kelayakan usaha yang telah dilakukan dan kendala yang mungkin muncul dalam pelaksanaannya.

\section{HASIL DAN PEMBAHASAN}

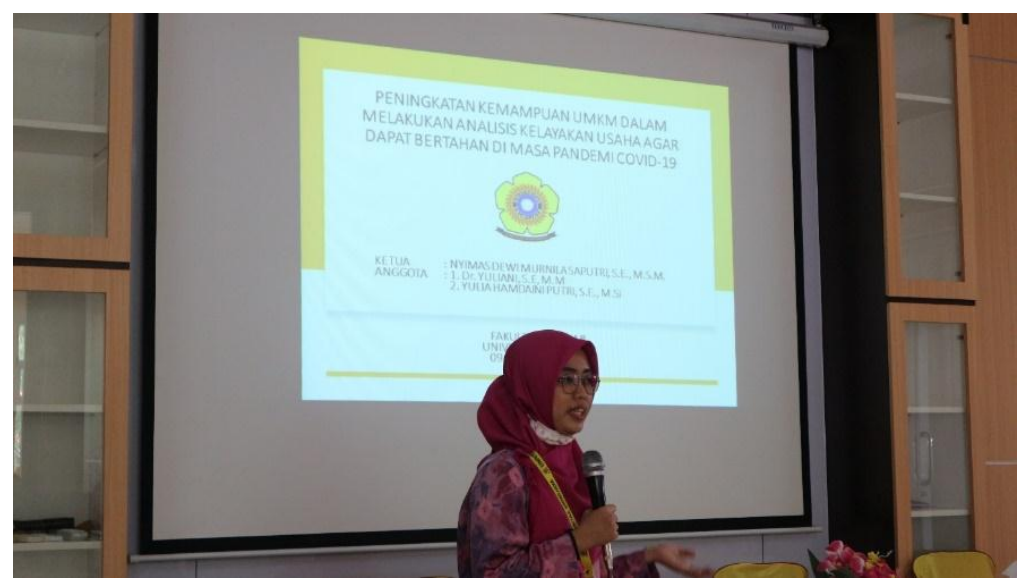

Gambar 1. Sesi Pelatihan dari narasumber

Kegiatan pengabdian kepada masyarakat yang berjudul "Peningkatan Kemampuan UMKM dalam Melakukan Analisis Kelayakan Usaha agar dapat Bertahan di Masa Pandemi COVID-19" telah dilaksanakan pada hari senin tanggal 09 November 2020 di Kantor Kecamatan Ilir Barat II Kota Palembang. Kegiatan pelatihan ini telah dihadiri oleh 30 peserta yang merupakan kelompok UMKM yang ada di Kota Palembang khususnya Kecamatan Ilir Barat II Kota Palembang dengan jenis usaha yang bergerak di bidang Songket, Suvenir, Kuliner, Penjahit dan Konveksi. Kegiatan 
pengabdian kepada masyarakat berupa pelatihan ini dilakukan dengan menerapkan protokol kesehatan sesuai dengan anjuran pemerintah yaitu penggunaan masker yang telah dibagikan, pengecekan suhu tubuh sebelum memasuki ruangan, menjaga jarak antar tempat duduk selama berlangsungnya kegiatan serta tersedianya handsinitizer di tempat yang mudah dijangkau peserta.

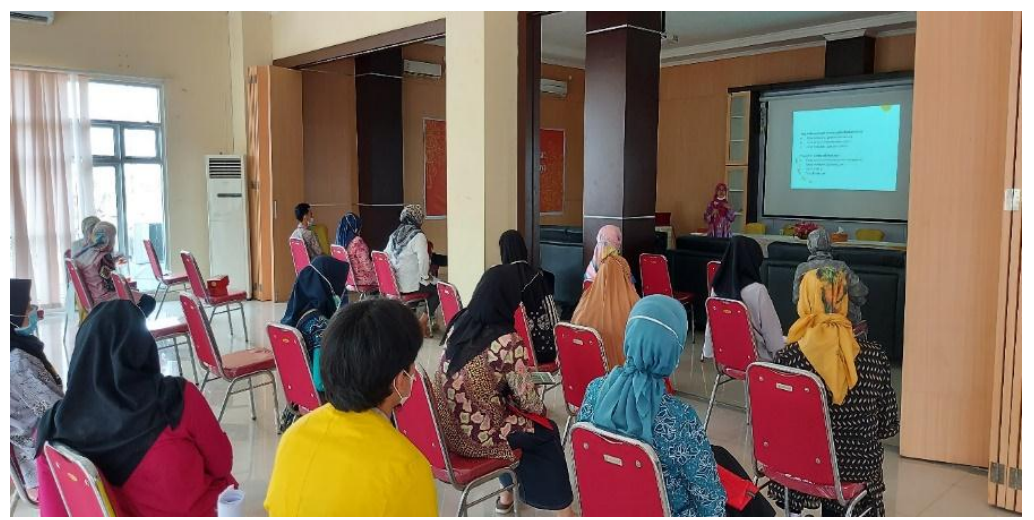

Gambar 2. Sesi Diskusi

Studi kelayakan adalah langkah yang dibutuhkan untuk memutuskan apakah kegiatan usaha dapat dilaksanakan atau dibatalkan. Dengan peningkatan kemampuan UMKM dalam melakukan kelayakan usaha merupakan salah satu cara untuk meningkatkan rencana pengembangan sebagai indikasi seberapa besar usaha yang dijalankan diharapkan lebih siap dan terencana apabila menghadapi situasi krisis. Analisis kelayakan usaha dipandang penting dilakukan, apalagi dikondisi yang tidak menentu saat pandemi sekarang ini. Keputusan dalam melakukan strategi kedepannya harus dinilai dulu layak atau tidak untuk dilakukan. Hal ini untuk menilai potensi peluang bertahan maupun daya saing UMKM ditengah masa pandemi.

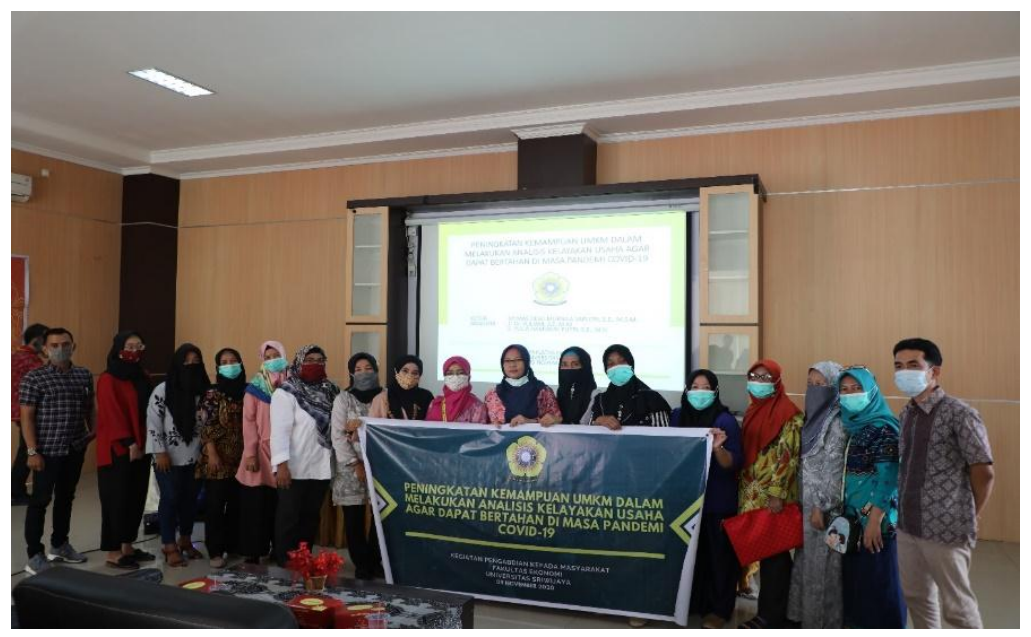

Gambar 3. Foto Bersama Peserta Pelatihan

Melalui kegiatan pengabdian ini mampu meningkatkan kemampuan UMKM di kota Palembang dalam melakukan analisis studi kelayakan usahanya ditengah masa pandemi COVID-19.

\section{SIMPULAN}

kegiatan pengabdian masyarakat ini bermanfaat bagi para pelaku UMKM yang ada di kecamatan Ilir Barat II Kota Palembang dapat diberikan edukasi dan pemahaman bagaimana menyusun analisis kelayakan usaha, sehingga kemampuan mereka dalam merencanakan bisnis meningkat ketika dihadapkan dengan berbagai macam kondisi yang ada. Hal ini dapat membuat UMKM mampu bertahan dan bersaing kedepannya. 


\section{UCAPAN TERIMA KASIH (ACKNOWLEDGMENTS)}

Penulis mengucapkan terima kasih kepada Universitas Sriwijaya yang telah memfasilitasi kegiatan pengabdian ini beserta semua pihak yang telah terlibat selama kegiatan.

\section{REFERENSI}

Afiyah, A., Saifi, M., \& Dwiatmanto. (2015). Analisis Studi Kelayakan Usaha Home Industry (Studi Kasus Pada Home Industry Cokelat "COZY" Kademanga Blitar). Jurnal Administrasi Bisnis (JAB), 23(1) 1-11.

Amilia, W. (2016). Agrocraft as a Creative Economy Development: Woven Bamboo. KnE Life Sciences, 3(3), 161-166. https://doi.org/10.18502/kls.v3i3.411.

Bank Indonesia. (2015). Profil bisnis usaha mikro, kecil dan menengah (UMKM). Jakarta: Lembaga Pengembangan Perbankan Indonesia (LPPI)

Gittinger, J.P. (1986). Analisis Ekonomi Proyek-Proyek Pertanian. Universitas Indonesia. (UI Pres). Jakarta

Hanoatubun, S. (2020). Dampak Covid - 19 terhadap Prekonomian Indonesia. EduPsyCouns: Journal of Education, Psychology and Counseling, 2(1), 146-153.

Jayanto, P., Mukhibad, H., \& Kuat Waluyo, J. (2018). Pendampingan UMKM Dalam Melakukan Analisis Kelayakan Usaha Untuk Meningkatkan Daya Saing. Seminar Nasional Kolaborasi pengabdian Pada Masyarakat, 22-26.

Mavilinda, H., Nazaruddin, A., Nofiawaty, N., Siregar, L., Andriana, I., \& Thamrin, K. (2021). Menjadi "UMKM Unggul" Melalui Optimalisasi Strategi Pemasaran Digital dalam Menghadapi Tantangan Bisnis di Era New Normal. Sricommerce: Journal of Sriwijaya Community Services, 2(1), 17-28. doi:https://doi.org/10.29259/jscs.v2i1.29

Nuraini, F., Maharani, R,. Andrianto. (2016). Strategi Peningkatan Daya Saing UMKM dan Koperasi Dalam Menghadapi AEC (Asean Economic Community): Suatu Telaah Kepustakaan. Prosiding Seminar Nasional Ekonomi dan Bisnis. Universitas Muhammadiyah Sidoarjo. 480-496.

Nurhayati. (2018). Pelatihan Pembuatan Studi Kelayakan Dan Proposal Kredit Bagi Usaha Mikro Kecil Dan Menengah (Umkm) (Studi Kasus: Kelurahan Sagulung Kota Kecamatan Sagulung Kota Batam Tahun 2017). Minda Baharu, 2(1), 63-70.

Peraturan Pemerintah Republik Indonesia Nomor 21 Tahun 2020 tentang Pembatasan Sosial Berskala Besar

Statistik, B. P. (2020). Analisis Hasil Survei Dampak Covid-19 Terhadap Pelaku Usaha. BPS RI.

Supriyanto. (2006). Pemberdayaan Usaha Mikro, Kecil, dan Menengah (UMKM) sebagai Salah Satu Upaya Penanggulangan Kemiskinan. Jurnal Ekonomi \& Pendidikan, 3(1), 1-16.

Susilo, A., \& et all. (2020). Coronavirus Disease 2019: Tinjauan Literatur Tekini. Jurnal Penyakit Dalam Indonesia, 7(1), 45-67. http://dx.doi.org/10.7454/jpdi.v7i1.415.

Undang-undang Republik Indonesia Nomor 20 tahun 2008 tentang UMKM

WHO International. (2020)

Winarni, S. (2006). Strategi Pengembangan Usaha Kecil Melalui Peningkatan Aksesibilitas Kredit Perbankan. Infokop Nomor 29 Tahun XXII, 2006. 